\title{
DIET ROTASI MAKANAN DAN MANIFESTASI KLINIS PENYANDANG SPEKTRUM AUTISME
}

\author{
Irma Suswati*, Fathiyah Safithri,**
}

\begin{abstract}
Abstrak
Autisme adalah gangguan perkembangan pervasif pada anak yang ditandai dengan adanya gangguan dan keterlambatan dalam bidang kognitif, bahasa, perilaku, komunikasi dan interaksi sosial. Penderita Autisme disertai alergi makanan sering mengalami gangguan sistem imun. Eliminasi makanan tertentu dapat mengurangi gangguan perilaku pada penderita Autisme. Tujuan penelitian ini untuk mengkaji implementasi diet rotasi makanan dan manifestaasi klinis yang timbul selama mengimplementasikan diet rotasi makanan pada penderita penyandang spektrum autisme dengan menggunakan rancangan penelitian observasional deskriptif, melalui kuesioner dan food diary.

Berdasarkan jenis kelamin penyandang speketrum autisme laki-laki sejumlab 7 orang (64\%) dan perempuan 4 orang (36\%). Hasil food diary yang dicatat oleh orangtua menunjukkan babwa sebagian besar telab mengimplementasikan diet sebat dengan memperbatikan jenis-jenis makanan yang diberikan kepada anak dan menerapkan diet rotasi 5 barian .

Manifestasi klinis berupa demam, kembung, konstipasi (kotoran keras, berak ngeden), nyeri perut, sering buang air besar P3 kali/ perbari), flatus, gatal di tungkai dan sela jari kaki dan lipatan kulit ketiak, berkeringat berlebib, pusing/memukul kepala, gangguan tidur, kejang, gangguan perilaku; teriak, gangguan belajar; tidak bisa konsentrasi, sering melamun, allergic sbiner (kulit di bawab mata tampak ke bitaman).

Reaksi yang tidak diinginkan terbadap makanan yang masuk kesaluran pencernaan merupakan reaksi simpang makanan yang dapat diperantarai oleb mekanisme yang bersifat imunologi, farmakologi, toksin, infeksi, idiosinkrasi, metabolisme serta neuropsikologis terhadap makanan dan jenis makanan yang memicu reaksi simpang merupakan makanan yang banyak. mengandung kasein, gluten, fenol, asam salisilat, bahan ragi, potassium, gas inggi, penyedap rasa, protein dan trans-fat yang dapat menyebabkan pertumbuhan jamur di usus dan menimbulkan reaki alergi yang mempengarubi semua organ.
\end{abstract}

Kata kunci Autis, diet, manifestasi klinis, alergi

Abstract

Autism is pervasive development disorder in cbildren shown by delay in cognate, language, bebavior, communication and social interaction. Autistic with food allergy often experience immunity system disorder. Eliminating certain food may decrease those disorders in autistic. The objective of the researcb is to examine the implementation of food rotation diet and clinical manifestation occur during the implementation of the diet in children with autistic spectrum disorder employing the research design of descriptive observation using questionnaire and food diary.

Based on sex the number of children with autistic spectrum disorder is 7 males (64\%) and 4 females (36\%). $\quad T \quad b \quad e$ food diary made by parents shows that most of them bave implemented bealtby diet and selected the types of food consumed during 5 -days rotation.

The clinical manifestation cover fever, beartburn, constipation, bemorrboids, diarrbea $>3$ times per day), flatulence, leg, armpit and feet itching, over sweaty, pain/bitting bead, sleep disorder, convulsion, bebavior disorder: screaming, learning difficulties; attention difficulties, spaced-out, allergic shiner.

Unexpected reaction toward the food consumed becomes food deviant reaction mediated by the mechanism of immunity, pbarmacology, toxicity, infection, idiosyncratic, metabolism and neuropsychology toward the food. The food type which results in food deviant reaction covers casein, gluten, phenol, salisilate acid, yeast, potassium, bigh gas, food additive, protein and trans-fat, that all support the growth of candida in intestine causing the allergy reaction which in tum affects all organs.

Keywords: Autism, diet, clinical manifestation, allergy

\footnotetext{
* Staff Pengajar Pada Fakulias Kedokteran

Universitas Mubammadiyab Malang
} 


\section{PENDAHULUAN}

Autisme adalah gangguan perkembangan pervasif pada anak yang ditandai dengan adanya gangguan dan keterlambatan dalam bidang kognitif, bahasa, petilaku, komunikasi dan interaksi sosial. Kaplan dan Morris melaporkan bahwa satu dari enam anak di Amerika menderita masalah-masalah seperti autisme, agresivitas dyslexia dan Attention Deficit Hyperactivity Disoder (ADHD) (McCandless, 2003).

Autism hingga saat ini masih belum jelas penyebabnya. Dari betbagai penelitian klinis hingga saat ini masih belum terungkap dengan pasti penyebab autisme. Secara ilmiah telah dibuktikan bahwa Autisme adalah suatu penyakit yang disebabkan oleh muktifaktorial dengan banyak ditemukan kelainan pada tubuh penderita. Terdapat beberapa hal yang dapat memicu timbulnya autism tersebut, termasuk pengaruh makanan atau alergi makanan. Alergi menimbulkan komplikasi yang cukup berbahaya, katena alergi dapat mengganggu semua organ atau sistem tubuh kita termasuk gangguan fungsi otak. Ada beberapa teori yang dapat menjelaskan bagaimana alergi dapat mempengaruhi fungsi otak, salah satunya adalah teori hipetpermeabilitas usus / simdroma leaky gut (usus bocor). Adanya gangguan dalam system pencernaan anak autis menyebabkan gangguan dalam mencerna protein khususnya protein dari susu (kasein) dan gandum (gluten). Rantai panjang asam amino tidak bisa dipecah menjadi asam amino tunggal, sehingga masih banyak yang dalam bentuk rantai pendek (peptide). Karena permeabilitas usus meningkat, peptida tersebut dapat dengan mudah menembus usus dan mencapai sirkulasi darah. Peptida bersama aliran darah akan mencapai otak dan selanjutnya akan berinteraksi dengan reseptor opioid di otak sehingga menimbulkan efek mirip morfin. Penelitian yang dilakukan Vodjani $\mathrm{dkk}_{3}$ tahun 2002 menemukan adanya beberapa macam antibody terhadap antigen. spesifik neuron pada anak autisme, diduga terjadi reaksi silang dengan protein ensefalitogenik dari susu sapi., Chlamydia pnemoniae dan streptococcus group A.

Penderita Autisme disertai alergi makanan sering mengalami gangguan sistem imun. Diantaranya adalah adanya gangguan beberapa tipe defisiensi system imun berupa defisiensi myeloperoxidase, Severe Combined Immunodeficiency Disease (SCID), defisiensi Ig A selektif, defisiensi komplemen $\mathrm{C} 4 \mathrm{~b}$ dan kelainan autoimun lainnya. Adanya gangguan tersebut mengakibatkan adanya gangguan sistem imun yang berfungsi menghancurkan jamur, virus dan bakteri. Hal ini mengakibatkan penderita autisme sering mengalami gangguan infeksi jamur (candidiasis), infeksi saluran napas dan mudah terkena penyakit infeksi lainnya secara berulang.

Eliminasi makanan tertentu dapat mengurangi gangguan perilaku pada penderita Autisme. Obanion dkk, tahun 1987 melaporkan setelah melakukan eliminasi makanan beberapa gejala autisme dan autisme infantil tampak membaik secara bermakna. Diagnosis pasti alergi makanan hanya dipastikan dengan Double Blind Placebo Control Food Chalenge (DBPCFC), namun pemeriksaan ini masih sangat terbatas. Penghindaran makanan penyebab alergi tidak dapat dilakukan hanya atas dasar hasil tes kulit alergi atau tes alergi lainnya. Oleh sebab itu dalam menentukan jenis makanan apa saja yang pếrlu dieliminir, orang tua yang memiliki anak autism harus mampu mengenali makanan yang menjadi penyebab alergi melalui pengamatan yang kemudian dibuat dalam bentuk catatan harian (food diary) tentang makanan yang dikonsumsi tiap hari dan efeknya pada prilaku, kemampuan komunikasi, konsentrasi dan lain-lain.

Tujuan penelitian ini untuk mengkaji implementasi diet rotasi makanan dan manifestaasi klinis yang timbul selama mengimplementasikan diet rotasi makanan pada penderita penyandang spektrum autisme.

\section{METODE PENELITIAN}

Penelitian akan dilakukan di SLB Autisme River Kid dengan menggunakan rancangan penelitian observasional deskriptif. Data diperoleh melalui kuesioner yang berisi catatan manifestasi klinis atau gejala yang timbul setelah makan makanan yang dikonsumsi dan food diary yang dilakukan harian memuat makanan yang dikonsumsi. Analisa data menggunakan analisis deskriptif untuk menjelaskan diet rotasi makanan dan manifestasi klinisnya. 


\section{HASIL DAN PEMBAHASAN}

SDLB Autis River Kids adalah lembaga pendidikan yang mendidik anak-anak berkebutuhan khusus agar anak menjadi mandiri dan bermartabat. SDLB River Kids berdiri sejak tahun 2004, dan jumlah siswa sebanyak 18 orang dengan jenis kelainan 7 otang $(40 \%)$ tuna grahita dan 11 orang $(60 \%)$ penyandang spektrum autisme. Berdasarkan jenis kelamin yang terbanyak penyandang spektrum autisme adalah laki-laki sejumlah 7 orang (64\%) dan perempuan 4 orang $(36 \%)$. Hal ini sesuai dengan Triantoro 2005, perbandingan jenis kelamin tiga kali lebih banyak pada laki-laki daripada perempuan. 11 orang. Penyandang spektrum autis seluruhnya betusia lebih dari 8 tahun.

Hasil food diary yang dicatat oleh orangtua menunjukkan bahwa sebagian besar telah mengimplementasikan diet sehat dengan memperhatikan jenis-jenis makanan yang diberikan kepada anak, seperti pada tabel berikut ;

Tabel 1. Jenis Makanan yang Dimakan oleh Penyandang Spektrum Autis

\begin{tabular}{|c|c|}
\hline 1 & Nasi, bihun, jagung, mie goreng \\
\hline 2 & $\begin{array}{l}\text { Sayur lodeh tewel, sayur tumis manisah, orem-orem, om clet sayur, gudeg, sop ayam, sayur } \\
\text { asem, sawi cah jagung manis, sayur brokoli, sayar bayam, oseng langkung, tim wortel, }\end{array}$ \\
\hline 3 & $\begin{array}{l}\text { Telur ayam kampung, telur asin, ceplok telur ayam kampong, lele goreng, ayam tepung, } \\
\text { ayam bumbu kecap, capjat, semur daging, kare ayam, ikan tengir, soto ayam, rawon, ikan } \\
\text { tongkol, mujair, bandeng, bakso. sosis }\end{array}$ \\
\hline 4 & Tempe, tahu rebus \\
\hline 5 & Susu kedele, susu soya \\
\hline 6 & Buah pir, semangka, jeruk, pisang ambon, apel, apokat, tomat, mangga, rambutan \\
\hline 7 & Nogosari, roti bahan non terigu, jemblem, kue donat \\
\hline 8 & Kerupuk, rengginang, bilatan asin, opak wijen, stik balado \\
\hline 9 & Jelly, nogosari, kacang goreng, coca-cola diet, permen, es kacang hijau \\
\hline 10 & Yakult, teh manis, teh rosella \\
\hline
\end{tabular}

Jenis makanan yang diberikan harian telah memenuhi gizi seimbang yang terdiri dari karbohidrat, protein, lemak, mineral dan vitamin, selain itu tampak diet yang diberikan bebas gluten dan kasein seperti susu kedele, susu soya, ; diet bebas zat adiktif seperti pewarna, pengawet, penyedap, dan pengemulsi yang dilakukan ibu dengan mengolah sayur maupun lauk sendiri, tidak membeli dalam bentuk jadi/kemasan, namun ada beberapa ibu yang memberikan anaknya gula murni dalam bentuk teh manis, sedangkan rotasi makanan yang diberikan pada anak sebagian besar $5-6$ hari menu betganti.

Sebelum menerapkan diet rotasi makanan ibu mengalami kesulitan mengidentifikasi makanan mana yang menjadi pemicu, menurut Mc Candless
(2003) Diet yang paling awal direkomendasikan bagi anak spektrum autisme adalah diet casein free gluten free, sebab dalam prakteknya efek diet produk olahan susu dapat terlihat dalam waktu 3 hari pada anak-anak sedangkan pada orang dewasa diperlukan 10-14 hari. Adapun untuk menghilangkan efek makanan dari gandum diperlukan waktu cukup lama bahkan sampai berbulan-bulan. Pada makanan lain yang tidak bersifat reaktif tetap perlu dirotasi paling sedikit 4harian. Hal ini disebabkan keterbatasan produksi enzym pada penyandang autisme. Adapun jenis makanan pemicu dengan manifestasi klinisnya tercantum pada tabel 2 
Tabel 2. Manifestasi Klinis dan Jenis Makanan Penyandang Spektrum Autis

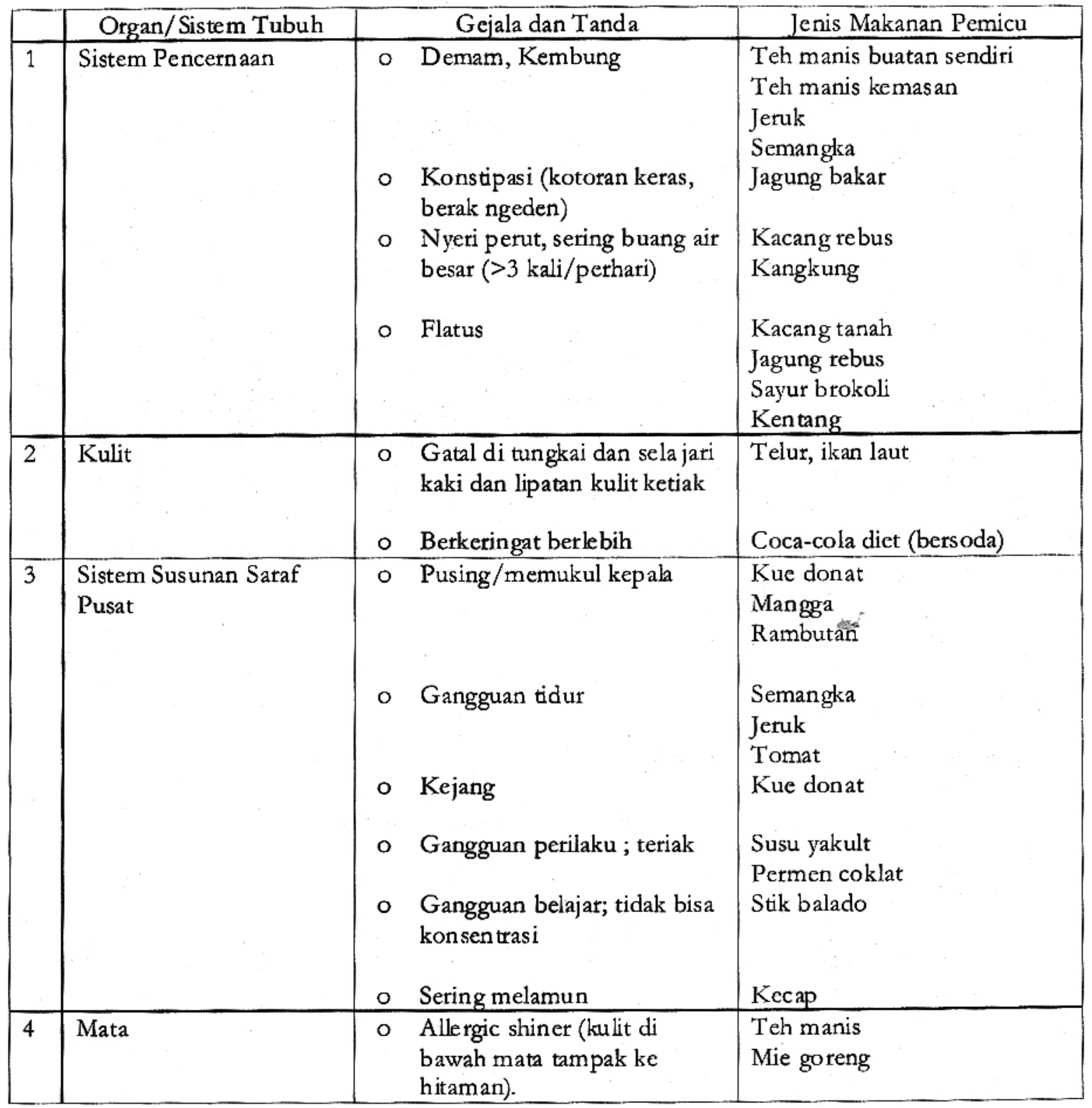

Reaksi yang tidak diinginkan terhadap makanan yang masuk kesaluran pencernaan merupakan teaksi simpang makanan yang dapat diperantarai oleh mekanisme yang bersifat imunologi, farmakologi, toksin, infeksi, idiosinkrasi, metabolisme serta neuropsikologis terhadap makanan (Widodo J, 2005). Reaksi simpang makanan bisa karena reaksi toksis seperti ketacunan makanan, selain itu bisa karena reaksi non toksis dengan melalui mekanisme imunologis seperti reaksi alergi makanan, penyakit celiac, gangguan absorbsi protein dan sindrom heiners, sedangkan reaksi non toksis yang melalui mekanisme non imunologis adalah intoleransi makanan, reaksi psikologis dan sebagainya.
Jenis makanan yang memicu reaksi simpang merupakan makanan yang banyak mengandung a) fenol contoh teh, semangka, apel, mangga, rambutan; b) asam salisilat contoh jeruk; c) berbahan ragi contoh; kecap, tempe; d) potassium contoh kentang, jagung; e) gas tinggi contoh kangkung, kacang, brokoli; f) kasein contoh susu yakult; g) gluten contoh mie goteng; h) penyedap rasa contoh stik balado; i) protein tinggi contoh telur, ikan laut.

Manifestasi klinis yang diamati oleh ibu yang paling mudah diidentifikasi adalah gangguan pencernaan dan gangguan susunan saraf yang dipengaruhi oleh berbagai jenis makanan. Menurut Atkins, Robert C, 2002 gejala klinis seperti kentut, 
kembung, sering melamun, gangguan tidur, gatal dan sebagainya merupakan gejala yang ditimbulkan akibat mengkonsumsi makanan yang memicu pertumbuhan jamur pada usus. Eades, Michael, 2002 menjelaskan usus merupakan organ penghancur makanan dan penyerap nutrisi makanan dan beberapa jenis makanan yang memiliki kandungan tinggi gluten, kasein dan gula (dari konsumsi karbohidrat tinggi) menyebabkan pertumbuhan jamur yang subur didalam usus, hal ini menyebabkan radang usus yang melemahkan sel pembentuk jaringan usus, sehingga tidak mampu memecahkan substansi protein peptida sehingga keluar dari usus dan masuk kepembuluh darah dan mengikat sistem kekebalan tubuh sehingga timbul reaksi berlebihan sebagai reaksi alergi.

Menurut Budhiman dkk, 2002: kasein dan gluten sangat dianjurkan untuk dipantang karena kandungan peptidanya meskipun dalam kadar rendah sangat peka bagi otak. Utamanya pada otak anak yang pernah mengalami bypoxia (otak kekurangan oksigen) atau anoxia (tidak mendapat oksigen sama sekali) selama proses kelahiran. dengan diet, peptida-opioid berkurang diharapkan imunitas meningkat dan pertumbuhan candida dapat ditekan sehingga permeabilitas (sifat mudah merembes) dạti dinding usus berkurang. Hal ini dapat diperparah dengan konsumsi gula dan makanan yang mengandung ragi. Selain itu permeabilitas usus tinggi karena rendahnya kandungan sulfat yang semestinya melapisi usus. Sulfat dalam usus tergerus katena anak mengkonsumsi makanan dengan kadar fenol tinggi, misalnya pada buah yang berubah warna setelah dikupas, coklat, obat parasetamol dan zat pewarna makanan. Pada anak spektrum autisme sistem sulfotransferase (pelapisan dinding usus dengan senyawa sulfat dan sulfit) tidak berfungsi sehingga mempengaruhi metabolisme neurotransmitter. Waring menemukan bahwa perubahan sulfit ke sulfat atau sistem GAGs (Glucosyl Acetyl Glucosamines) terhalang setelah anak mendapat imunisasi hepatitisB.

Menurut Widodo J, 2005 gangguan saluran cerna merupakan gangguan yang paling sering dikeluhkan pada anak autis, secara mekanik integritas mukosa usus dan peristaltik merupakan pelindung masuknya alergi ke dalam tubuh dan secara kimiawi asam lambung dan enzim pencernaan menyebabkan rusaknya bahan penyebab alergi (denaturasi allergen) dan secara imunologik sIgA pada permukaan mukosa dan limfosit pada lamina propia dapat menangkal allergen (penyebab alergi) masuk ke dalam tubuh dan reaksi alergi dapat mengganggu semua organ atau sistem tubuh kita tanpa terkecuali, khususnya saluran cerna.

Reaksi simpang makanan juga memberikan gejala klinis pada kulit. Karakteristik gangguan kulit yang ditimbulkan sangat bervariasi. Pada bayi sering timbul dermatitis di pipi dan "diapers dermatitis". Pada anak yang lebih besar sering urticaria (gatal), miliaria (biang keringat), bengkak di bibir, vaskulitis atau pembuluh darah yang pecah) dengan gambaran lebam biru kehitaman seperti bekas terbentur, bercak ke hitam seperti bekas digigit nyamuk, lokasi alergi kulit biasanya pada pelipatan dalam antara lengan atas dan bawah atau pelipatan dalam antara tungkai atas dan bawah. Petbedaan lokasi aletgi kulit sesuai dengan usia tertentu.

Alergi pada anak dapat menyerang semua organ tanpa terkecuali mulai dari ujung rambut sampai ujung kaki dengan berbagai bahaya dan komplikasi yang mungkin bisa terjadi dan telah terungkap alergi menimbulkan komplikasi yang cukup berbahaya, karena alergi dapat mengganggu fungsi otak. Gangguan fungsi otak dapat menyebabkan timbul ganguan petkembangan dan perilaku pada anak seperti gangguan hiperaktifitas, gangguan emosi, gangguan perkembangan motorik, gangguan tidur malam, gangguan konsentrasi hingga memperberat gejala ADHD dan Autis. Dari semua reaksi yang tidak diinginkan terhadap makanan dan zat aditif makanan hanya sekitar $20 \%$ disebabkan karena alergi makanan (Widodo J, 2005)

Penanganan reaksi simpang makanan dengan gangguan neurologi dan gangguan perilaku harus dilakukan secara holistik. Selain menghindari makanan penyebab maka diperlukan penanganan multidisiplin ilmu kesehatan anak. Bila perlu harus melibatkan bidang neurologi, psikiater, tumbuh kembang, endokrinologi, alergi imunologi, gastroenterologi dan bidang ilmu kesehatan anak lainnya. 


\section{DAFTAR PUSTAKA}

Atkins, Robert C. 2002. Dr. Atkins' New Diet Revolution. New York. M.Evans and Company. Inc

Budhiman, M., Shattock, P, dan Ariani, E. 2002. Langkah Awal Menanggulangi Autisme dengan Memperbaiki Metabolisme Tubuh. Jakarta: Nirmala.

Doman, G. 2006. Apa yang Dapat Dilakukan pada Anak Anda yang Cedera Otak. Jakarta: GR Press.

Elvi Andriani, 2003, Autisme: Masa Anak, Program Studi Psikologi Fakultas Kedokteran Universitas Sumatra Utara, (diakses dari www,puterakembara.com )

Eades, Michacel R dan Eades, Mary Da. 2002. The Protein Power Lifeplan: A New Comprebensive Blue Print for Optimal Health. New York: Wasner Books. Ins

Ginanjar, A.S. 2007. Memabami Spektrum Autistik Secara Holistik. Disertasi (diakses dari www.putrakembara.com tanggal 20 Agustus 2007)

Handojo, Y. 2004. Autisma: Petunjuk Praktis of Pedoman Materi untuk Mengajar Anak Normal, Autis dan Prilaku Lain. Jakarta: Gramedia

Hananto W, 2002. Peningkatan Gizi Bayi, Anak, Ibu Hamil, dan Menyusui dengan Baban Makanan Lokal. Jakarta. Sagung Seto

Hitti, M. 2004. Gender Affects Language in Autistic Children. WebMD medical news

Jim Adam, Overview of Autism Research, Testing, and Treatments, (diakses dari www.puterakembara.com )

McCandless, J. 2003. Children with Starving Brains Anak-anak dengan Otak yang "Lapar": Panduan penanganan medis untuk penyandang gangguan spektrum autisme, ed.2. Jakarta: Grasindo

Staum, M.J. 2004. Music Therapy and Language for The Autistic Cbild. Diakses dari www.percepp.demon.co.uk/autism.htm

Triantoro S, 2005. Autisme Pemabaman Baru untuk Hidup Bermakna bagi Orang Tua. Yogyakarta. Graha Ilmu.

Vodjani A et al, 2002. Antibodies to Neuron-Specific Antigens in Children with Autism: Possible Crossreaction with Encephalitogenic Proteins from
Milk, Chlamydia pneumoniae, and Streptococcus group $A$. J Neuroimmunol, 129:168-177.

Widodo Judarwanto, 2005, Alergi Makanan, Diet dan Autisme, Makalah yang dipresentasikan pada seminar di Hotel Novotel 9 September 2005. (diakses www.puterakembara.com ) 